( anton Valais, being ${ }_{1}{ }_{3} S_{5}$ metres, and in Canton St. Ciall only 270 metres.

Sometimes these pines form distinct and close-grown woods, to the exclusion of other conifers, in which each one is similarly developed. Such woods, however, are not common, and are generally restricted to the Grisons and Canton Valais, where the Arve is most abundant. More often, however, even when not mixed with other kinds, individuals grow either in more open order or in small clusters, or even as solitaries. Or the slopes of the northern Alps they not unfrequently form trailing lines, the trees in which, as might be expected, often bear the marks of storm and stress. But the Arve more commonly is associated with other conifers-the larch, the spruce, the Scotch fir, and sometimes the silver fir. Another, but more lowly companion, is the Legföhre (Pinus montana), that trailing conifer which is more abundant in the eastern than in the western Alps, and altogether absent, so far as Dr. Rikli knows, from the Valais and the Oberland. The Arve also grows in company

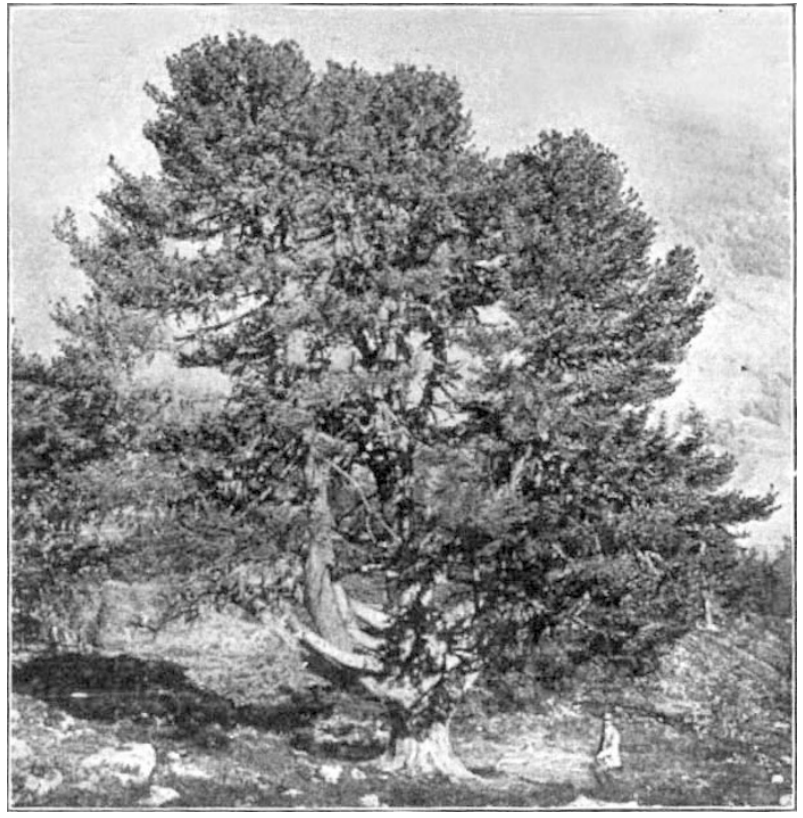

FIg. 2. - The Arve in Age.

with other trees and bushes, such as the birch, the beech, the Alpine alder, a service (Sorbus aucuparia), and, of course, with the common rhododendron (R. ferrugineum), the bearberry (Arctostaphylos uvaursi), the bilberry (Vaccinium myrtillus), and another member of that genus; while in the associated flora a mid-Europe Alpine, a north-Europe Alpine, and an Arctic-Altaian element may be detected; the last, as Dr. Rikli remarks, forming a link with the Arve's original home.

This memoir describes, with illustrations from reproduced photographs, the modes of growth which, according to circumstances, the Arve exhibits. A solitary one, when in its full vigour, is a happy combination, as Fig. I proves, of beauty and strength. With the advance of age it is apt to lose its symmetry and compactness, though it is still, as Fig. 2 shows, an ornament to the landscape. No more than other trees does it escape being torn by the storm or the avalanche, shattered by the lightning, and nipped, especially when young, by exceptionally NO. 2 IOI, VOL. 82] severe frosts; but when overthrown, it sometimes puts out new roots and converts side branches into leading stems. But the Arve has its enemies also among other living things. Man is responsible for reckless hacking and felling, for forest fires or damage done in climbing after its cones, the kernels in. which have a nut-like flavour. But now that he is restrained by forest laws, other creatures are the more formidable. Goats, sheep, and cattle (especially the first, if carelessly tended) do much damage to the young plants; the roe-deer, the stag, and the chamois take their share when in search of food. The marten, the squirrel, and even the fox, feed on the nuts, though the last, like the wood and hazel mice, must wait until they have fallen. Some birds also have similar tastes. Most conspicuous among these is the nutcracker (Nucifraga caryocatactes), which is never so common in the Alps as where the Arve is plentiful and its fruit is ripening. The capercaillie (Tetrao. urogallus) feeds on the young shoots, and the common sparrow, generally to the front in mischief, has. been known to do the same with seedlings. Its insect foes we can only mention.

In short, Dr. Rikli seems to have touched on every point of interest in the life-history of Pinus cembra in Switzerland, and has done his work with Teutonic thoroughness. He goes over the country, canton by canton, and valley by valley, citing statistics of the numbers of the trees, their distribution on either slope, and other distinctive features; he gives many particulars of the age, size, and rate of growth of the older trees, and refers to the care which, of late years, has been bestowed on their culturé. The maps appended to the volume are interesting as showing the relative abundance or scarcity of Pinus cembra in different districts of the Alps, and the numerous photographs, especially the eighteen separately printed, some of which are unusually good, recall to lovers of that mountain chain pleasant memories of this handsome tree. To such Dr. Rikli's work will always be attractive; but to students of forestry it will be indispensable.

T. G. B.

\section{ON HALLEY'S COMET AS SEEN FROM THE EARTH.}

THE following table gives ecliptic coordinates of Halley's comet to two decimal places at intervals of four days through an arc extending from one end to the other of the latus rectum of its orbit. The zero of time is very nearly the moment of perihelion passage, and the figures apply approximately to any return.

$$
\begin{array}{rccc|cccc}
\text { Day } & x & y & z & \text { Day } & x & y & z \\
-52 & +0.95 & +0.73 & +0.12 & +4 & +0.21 & -0.54 & +0.15 \\
-48 & +0.93 & +0.64 & +0.13 & +8 & +0.10 & -0.59 & +0.13 \\
-44 & +0.91 & +0.55 & +0.14 & +12 & -0.02 & -0.64 & +0.11 \\
-40 & +0.89 & +0.46 & +0.15 & +16 & -0.13 & -0.67 & +0.09 \\
-36 & +0.86 & +0.37 & +016 & +20 & -0.24 & -0.69 & +0.06 \\
-32 & +0.83 & +0.27 & +0.17 & +24 & -0.34 & -0.70 & +0.04 \\
-28 & +0.80 & +0.18 & +0.18 & +28 & -0.45 & -0.71 & +0.01 \\
-24 & +0.75 & +0.09 & +0.18 & +32 & 0.55 & -0.71 & -0.02 \\
-20 & +0.70 & -0.02 & +0.19 & +36 & -0.64 & -0.70 & -0.04 \\
-16 & +0.65 & -0.12 & +0.19 & +40 & -0.74 & -0.70 & -0.07 \\
-12 & +0.58 & -0.21 & +0.19 & +44 & -0.83 & -0.68 & -0.09 \\
-8 & +0.50 & -0.31 & +0.19 & +48 & -0.91 & -0.67 & -0.12 \\
-4 & +0.41 & -0.39 & +0.18 & +52 & -1.00 & -065 & -0.14 \\
0 & +0.31 & -0.47 & +0.17 & & & &
\end{array}
$$

The comet attains unit distance from the sun thirty-nine days before and after perihelion passage. On the former occasion its $z$ coordinate perpendicular to the ecliptic is $+0^{\circ} \mathrm{I} 5$, on the latter $-0^{\circ} 07$. It is evident, therefore, that the closest possible approach to the earth will occur after perihelion passage. The 
heliocentric longitude is $30^{\circ}$ on the earlicr occasion and $225^{\circ}$ on the later. The earth reaches these heliocentric longitudes in October and May respectively.

At the return of 1835 perihelion passage was on November 16 . There was consequently a close approach between the earth and the comet about a month earlier. In I9 Io the perihelion passage will be on April 20; a month earlier than this, when the comet is close to the earth's orbit, the earth will be at the diametrically opposite point. A month after perihelion, however, there will be a very close approach.

The most unfortunate date for perihelion passage for yielding a close approach to the earth is January. The comet would then be behind the sun at perihelion, and more than an astronomical unit itway when crossing the earth's orbit.

On the present return the approach after perihelion will be unusually close. The following table gives the wliptic coordinates of the earth for the annexed dates:--

$\begin{array}{cccccc}\begin{array}{c}\text { Date } \\ \text { I.910, May Io }\end{array} & \ldots & -0.65 & \ldots & -0.76 \\ ,, & \text { I4 } & \ldots & -0.60 & \ldots & -0.80 \\ ,, & \text { I8 } & \ldots & -0.55 & \ldots & -0.84 \\ ,, & 22 & \ldots & -0.49 & \ldots & -0.87 \\ , & 26 & \ldots & -0.43 & \ldots & -0.90 \\ , & 30 & \ldots & -0.37 & \ldots & -0.93\end{array}$

When, therefore, the comet crosses the plane of the ecliptic twenty-eight days after perihelion passage (May I8) it will be almost exactly between the earth and the sun, and the earth will probably be in the tail of the comet.

The closest approach at this return takes place a day or two later.

The closest approach possible would correspond to a perihelion passage about a week and a half earlier in the year than the present one.

It appears, therefore, that the date of perihelion passage at this return is most fortunately timed, and a fine display may be expected.

The comet's history has been traced back to 240 B.c., and it has very seldom returned to perihelion unrecorded; so seldom, in fact, as to suggest that in the exceptional cases the records

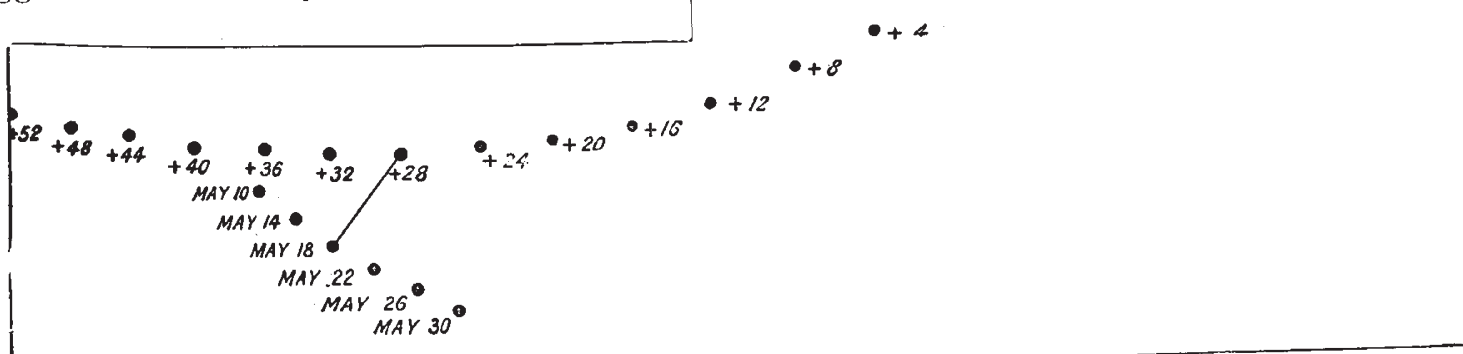

The diagram gives the position of the Earth for six days in May; also the position of the comet on twenty-seven dat:s measured from perihelion passage in day's. The line of sight is drawn for May 18, twenty-eight days afier perihelion, when tue comet iransits across the Sun.

have perished rather than that the comet in any circumstances can pass by unseen.

A tail twenty or thirty degrees in length is expected on the present occasion. It will be best seen at the end of May, and in England it will, unfortunately, be lower in the sky than in more southern latitudes. There will, however, be no difficulty whatever in seeing it in England, unless there is a prolonged spell of bad weather.

The approach to the earth is so close that an American astronomer has conceived the idea of weighing the comet by the deviation it produces in the orbit of the earth. We can hardly believe that the effect NO. 2101, VOL. 82] produced will be one-thousandth part of the least measurable quantity, but the speculation is most interesting in view of the fact that there are unexplained phenomena in planetary movements.

P. H. Cowell.

JUBILEE OF THE THEORY OF ELECTROLYTIC DISSOCIATION. ${ }^{2}$

$\mathrm{I}$ his address to the British Association in $\mathbf{1 8 8 4}$, the president, Lord Rayleigh, said, "from the further study of electrolysis we may expect to gain improved views as to the nature of chemical reactions, and of the forces concerned in bringing them about.

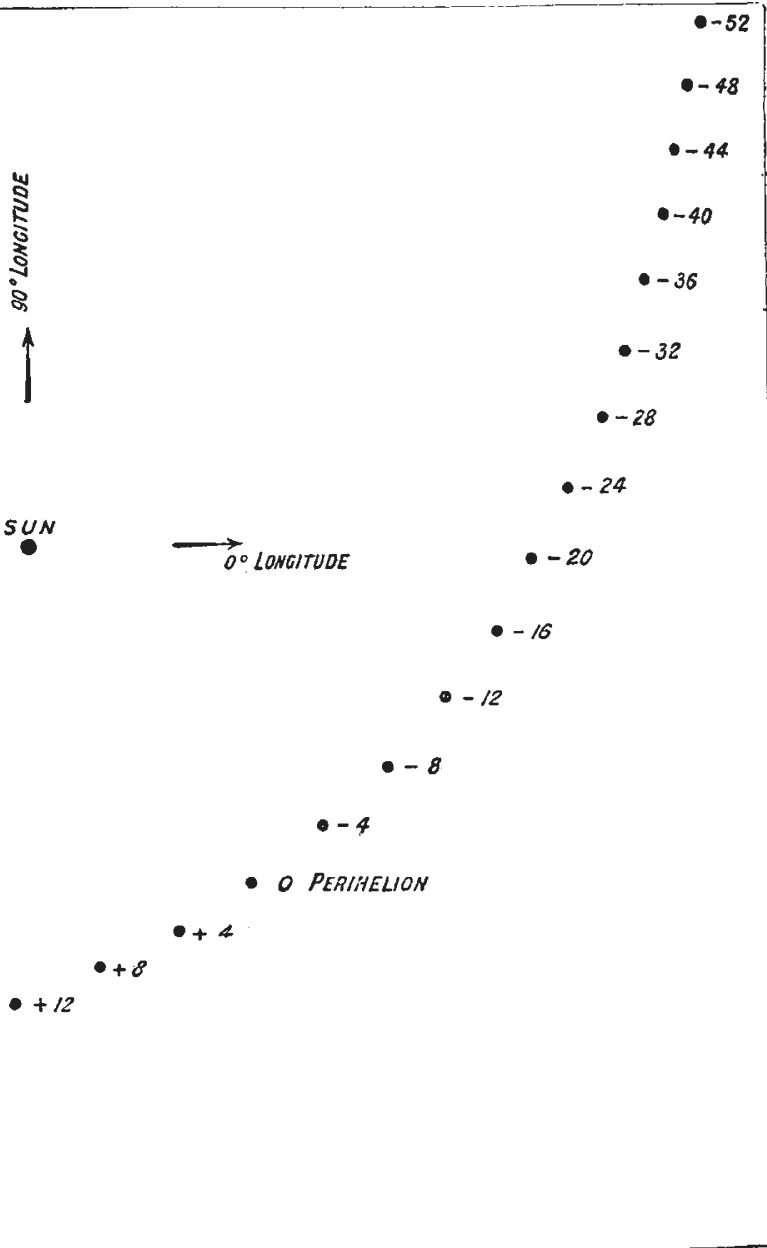

... I cannot help thinking that the next great advance, of which we have already seen some foreshadowing, will come on this side."

The first step of the advance spoken of by Lord Rayleigh had already been made, for in that same year the young Swedish physicist, Arrhenius, presented as his doctor's dissertation to the University of Upsala a memoir with the title "Recherches sur la Conductibilité galvanique des É lectrolytes. Première Partie: La Conductibilité des Solutions aqueuses ex1 Zeitschrift fïr physikalische Chemie. Bd. 69, Jubelband. Svante Arrhenius zur Feier des 25 -jährigen Bestandes seiner Theorie der elektrolyt. ischen Dissociation gewidmet von seinen Freunden und Schülern. Mit einer Einleitung von W. Ostwald. Pp. xxix +685. (Leipzig: W. Engelmann, i gog.) 